\title{
Effect of seventeen rootstocks on young 'Valência' sweet orange performance in western Santa Catarina, Brazil
}

Brugnara, E. C. and Sabião, R. R.

DOI: $10.31047 / 1668.298 x . v 38 . n 1.27977$

\begin{abstract}
SUMMARY
Recommendations of rootstocks for 'Valência' sweet orange in southern Brazil have been partially based on empirical observations or information. Therefore, this study compared young 'Valência' trees budded on different rootstocks in western Santa Catarina, Brazil. Seventeen rootstocks were tested for growth (tree height and canopy projection area and volume) and fruit production (per tree, hectare, $\mathrm{m}^{2}$ and $\mathrm{m}^{3}$ of canopy). The experiment comprised four replicates of three trees and was carried during six years under standard management, in a Cfa (humid subtropical) climate. In general, larger trees produced more fruit. However, 'San Diego' citrandarin, 'Swingle' citrumelo, 'Cravo' rangpur lime (among vigorous rootstocks), 'Cravo' x 'Sunki' EEl hybrid, 'Fepagro C37 Dorneles' citrange, 'Rubidoux' trifoliate orange (among medium vigorous rootstocks), 'HFD25 EEl' hybrid and 'Flying Dragon' trifoliate orange (among less vigorous rootstocks) stood out in cumulated production by area or volume of the canopy. 'San Diego' also stood out in production per tree. Cultivars 'Cravo' x 'Sunki' EEI, 'San Diego', and 'HFD25 EEl' should be further evaluated regarding disease susceptibility and fruit quality for possible release.
\end{abstract}

Key words: Citrus sp.; Poncirus trifoliata; grafting; yield; vigor.

Brugnara, E. C.y Sabião, R. R., 2020. Efecto de diecisiete portainjertos en el desempeño de la naranja dulce 'Valência' en el oeste de Santa Catarina, Brasil. Agriscientia 38: 51-57

\section{RESUMEN}

La recomendación de portainjertos para el naranjo 'Valência' en el sur de Brasil se ha basado parcialmente en observaciones o información empírica. Este estudio comparó árboles jóvenes de 'Valência' injertados en diferentes portainjertos en el oeste del estado de Santa Catarina, Brasil. Se compararon diecisiete portainjertos en cuanto al crecimiento (altura de los árboles y volumen y área de proyección de copa) y producción de frutos (por árbol, hectárea, $\mathrm{m}^{2}$ 
y $\mathrm{m}^{3}$ de copa). El experimento estuvo compuesto por cuatro réplicas de tres árboles, y se realizó durante seis años, en un clima subtropical húmedo (Cfa) bajo manejo estándar. En general, árboles mayores produjeron más frutos. Entretanto, el citrandarin 'San Diego', el citrumelo 'Swingle', la lima 'Cravo' (entre los portainjertos vigorosos), el híbrido 'Cravo' x 'Sunki' EEl, el citrange 'Fepagro C37 Dorneles', el trifolio 'Rubidoux' (entre los portainjertos de vigor medio), el híbrido 'HFD25 EEl' y el trifolio 'Flying Dragon' (entre los portainjertos menos vigorosos) se destacaron en producción por área o volumen de copa, y 'San Diego' también en producción por planta. Las cultivares 'Cravo' x 'Sunki' EEI, 'San Diego' y 'HFD25 EEl' deben evaluarse con respecto a susceptibilidad a enfermedades y calidad de frutos para posible lanzamiento.

Palabras clave: Citrus sp.; Poncirus trifoliata; injerto; producción; vigor.

Brugnara, E. C. (ORCID: 0000-0001-9894-2714) and Sabião, R. R. (ORCID: 0000-0003-1910-4064): Empresa de Pesquisa Agropecuária e Extensão Rural de Santa Catarina, Centro de Pesquisa para Agricultura Familiar (EPAGRI/Cepaf), Chapecó, Brazil. Correspondence to: eduardobrugnara@epagri.sc.gov.br

\section{INTRODUCTION}

Environmental stress in the form of droughts, floods, frosts, high temperature, pests and diseases are factors that can negatively affect citrus trees growth. In order to overcome these challenges, growers can combine scion and rootstock varieties through grafting (Ribeiro, Espinoza-Núñez, Pompeu, Mourão Filho and Machado, 2014). When choosing a rootstock, growers must take into account a list of attributes. Castle (2010) suggests twenty-four attributes concerning yield and reaction to biotic and abiotic soil characteristics, among others.

In subtropical southern Brazil, 'Valência' sweet orange [Citrus sinensis (L.) Osbeck] is an important scion cultivar, especially due to its late harvest. However, sweet oranges are susceptible to soil diseases that damage roots and the trunk collar, such as Phytophthora sp. root rot. This leads growers to graft 'Valência' onto Phytophthora tolerant rootstocks if the orchard's soil is finetextured. In addition to disease tolerance, tree vigor and yield, cold hardiness, and fruit quality are important traits to take into account to choose a rootstock. Trifoliate orange [Poncirus trifoliata (L.) Raf.] and its hybrids (citranges and citrumelos) have been recommended by citrus experts and governmental agencies. However, especially in Santa Catarina State, citrus nurserymen prefer fast growing rootstocks, which shorten nursery tree growing time, such as 'Cravo' (Rangpur) lime
(Citrus limonia Osbeck), a Phytophthora sensible genotype, and 'Swingle' citrumelo (Citrus paradisi Macfad $\times$ P. trifoliata).

In general, recommendations of rootstocks for 'Valência' orange cultivation in the states of Rio Grande do Sul and Santa Catarina are partially based on empirical observations or data from other scion cultivars, since scientific works regarding rootstocks for 'Valência' are scarce. Some studies have already been carried in medium-textured soils of southern Rio Grande do Sul (Koller, Marodin, Schwarz and Nienow, 1988; Koller, Schwarz and Panzenhagen, 1999; Kirinus et al., 2019), therefore, this study compared the agronomic performance of young 'Valência' sweet orange grafted on 17 rootstocks, in western Santa Catarina, Brazil.

\section{MATERIAL AND METHODS}

The experiment was carried out in the municipality of Águas de Chapecó, Santa Catarina State, Brazil, in the Rio Uruguay valley region, at $330 \mathrm{~m}$ above sea level, and in a humid subtropical climate (Koppen - Cfa). The soil (Nitisol, 30-40 \% clay) was previously corrected for $\mathrm{pH}, \mathrm{P}$ and $\mathrm{K}$ levels. Standard 'Valência' sweet orange nursery plants were transplanted in May 2013, following the experimental treatments (rootstocks) described below and spaced $7 \mathrm{~m} \times 3 \mathrm{~m}$.

The experiment was designed in four completely random blocks with three-tree plots. Seventeen 
rootstocks genotypes were tested:

1. 'Swingle' citrumelo

2. 'Fepagro C37 Dorneles' citrange (C. sinensis x P. trifoliata)

3. 'Carrizo' citrange

4. 'C 35' citrange

5. 'Fepagro C 13' citrange

6. 'Flying Dragon' trifoliate orange (P. trifoliata var. monstrosa)

7. 'SCS453 Nasato' trifoliate orange (P. trifoliata)

8. 'Rubidoux' trifoliate orange

9. 'BRS CNPMF Tropical' mandarin [C. sunki (Hayata) hort. ex Tan.)]

10. 'Sun Chu Sha Kat' mandarin (C. reticulata Blanco)

11. 'Cravo' rangpur lime (C. limonia Osbeck)

12. 'HFD 25 EEl', F1 from open-pollination of $P$. trifoliata 'Flying Dragon'

13. 'HFD 11 EEl', F1 from open-pollination of $P$. trifoliata 'Flying Dragon'

14. 'Sunki' x 'Benecke' citrandarin (C. sunki x P. trifoliata)

15. 'San Diego' citrandarin (C. sunki $\times \quad P$. trifoliata).

16. 'Changsha' x 'English Large Trifoliate' citrandarin $(C$. reticulata $\times P$. trifoliata)

17. 'Cravo' x 'Sunki' EEI (C. limonia x C. sunki).

Trees were grown following standard procedures for orange growing in Santa Catarina State. Fertilizations were performed considering the expected average production (Rockenbach and Koller, 2013), keeping the same doses across the treatments. In August 2013, all trees were pruned at $50 \mathrm{~cm}$ from the ground, selecting later three to four new shoots for canopy formation. No further pruning was made to avoid limiting expression of rootstock vigor. Fungicides were regularly sprayed during flowering and fruitlet times.

Tree height $(H)$ and canopy diameter (D) (average of transversal and longitudinal to the row) were measured in May 2019. This basic data was used to calculate additional output variables, namely canopy volume $(\mathrm{V})(\mathrm{V}=2 / 3 \omega \times \mathrm{H} \times \mathrm{D})$ and projection area $(\mathrm{PA})\left(\mathrm{PA}=\varpi \times(\mathrm{D} / 2)^{\wedge} 2\right)$, canopy shape index (H/D ratio), cumulated fruit production per tree (ignoring dead ones) for 3-6 years $(P)$, cumulated fruit production per hectare considering zero the production of dead trees, productive efficiency index by volume (P/N ratio), and area ( $\mathrm{P} /$ PA ratio).

The output variables were submitted to the BoxCox test to verify data suitability (and transform it if necessary) for further analysis of variance (ANOVA). The rootstock means were compared by the ScottKnott grouping test $(\alpha=0.05)$. The relation between variables was analyzed through the Principal Component Analysis (PCA). All analyses used "R" software provided with "ScottKnott", "MASS" and "Agricolae" packages (R Core Team, 2018).

\section{RESULTS AND DISCUSSION}

All eight variables of response were significantly affected by the rootstocks (Table 1). 'Valência' trees grew less when budded on 'Flying Dragon' and 'HFD 25 EEl' (1.51 m and $1.72 \mathrm{~m}$ high, respectively) and grew more on a group of seven rootstocks whose heights were statistically the same $(3.13 \mathrm{~m}$ to $3.56 \mathrm{~m}$ ) (Figure 1a). Other eight treatments had an intermediate height (2.46 $\mathrm{m}$ to $2.89 \mathrm{~m}$ ). 'Flying Dragon' and 'HFD 25 EEl' showed a significantly smaller shape index too, lower than 0.89, while the other 15 rootstocks ranged from 0.97 to 1.15 without differing significantly from each other (Figure 1b).

Canopy volumes and projection areas tended

Table 1. Data transformation and outputs in the analysis of variance for eight variables evaluated in 'Valência' sweet orange [Citrus sinensis (L.) Osbeck] under the effect of rootstocks in a randomized block design

\begin{tabular}{lcccc}
\hline \multirow{2}{*}{ Variable } & \multicolumn{3}{c}{ Rootstock effect } \\
\cline { 2 - 5 } & Transformation & $F$ value & $p$ value & Coefficient of variation \\
\hline & & & & $(\%)$ \\
Tree height & - & 17.12 & $1 \times 10^{-14}$ & 9.46 \\
Canopy projection area (PA) & - & 12.23 & $7 \times 10^{-12}$ & 14.56 \\
Canopy volume (V) & $y^{0.5}$ & 17.13 & $1 \times 10^{-14}$ & 10.80 \\
Canopy shape & - & 7.59 & $1 \times 10^{-5}$ & 4.63 \\
Tree production (P) & $y^{0.5}$ & 9.36 & $7 \times 10^{-10}$ & 12.64 \\
Hectare production & $y^{0.5}$ & 11.19 & $3 \times 10^{-11}$ & 11.85 \\
P/PA & - & 3.75 & 0.000193 & 17.72 \\
P/V & $y^{-0.1}$ & 4.29 & $4 \times 10^{-5}$ & 1.96 \\
\hline
\end{tabular}


(a)

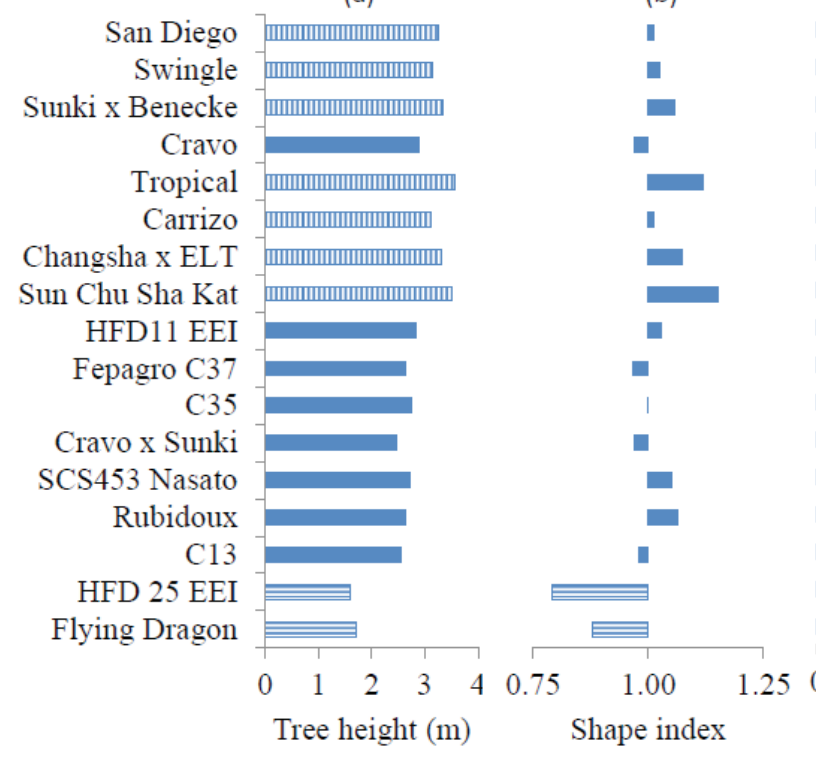

(e)

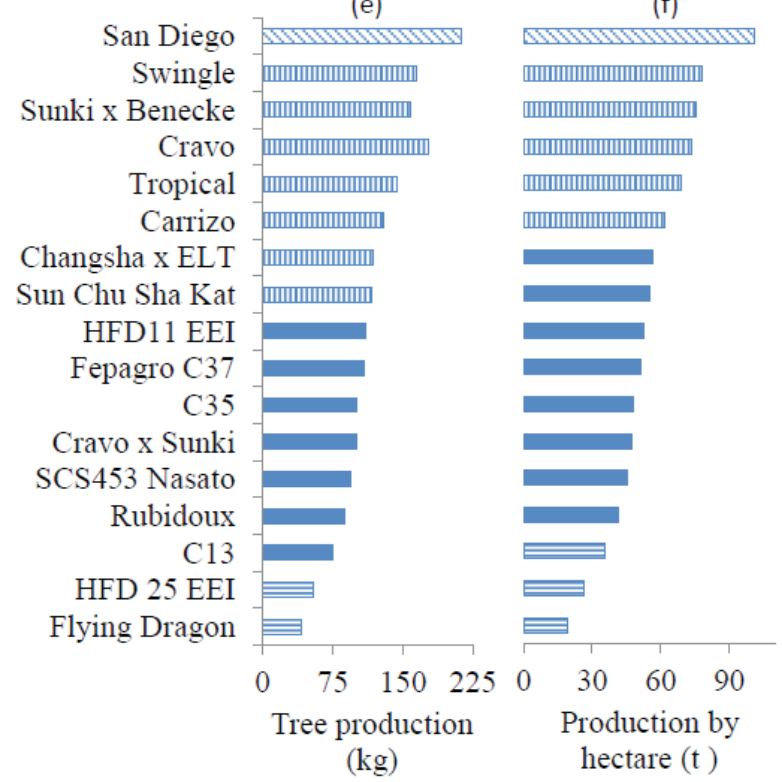

(c)

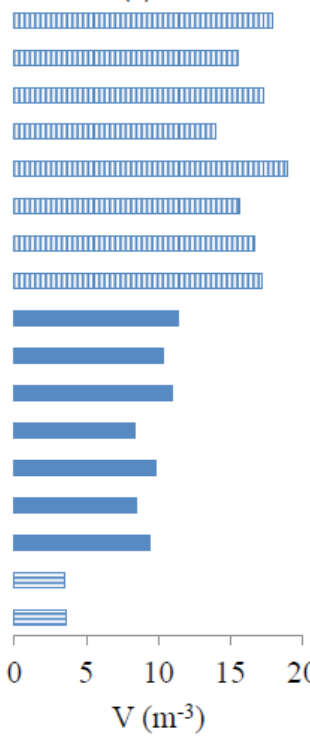

(g)

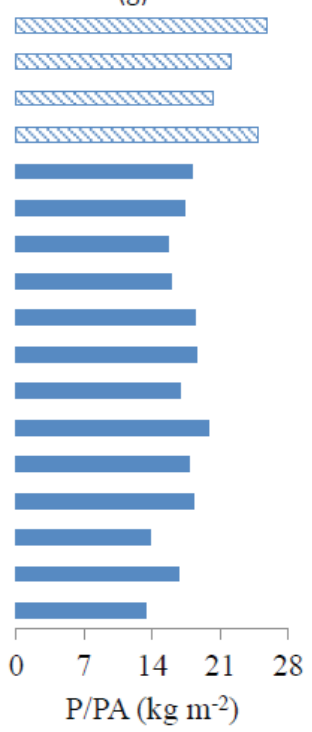

(d)

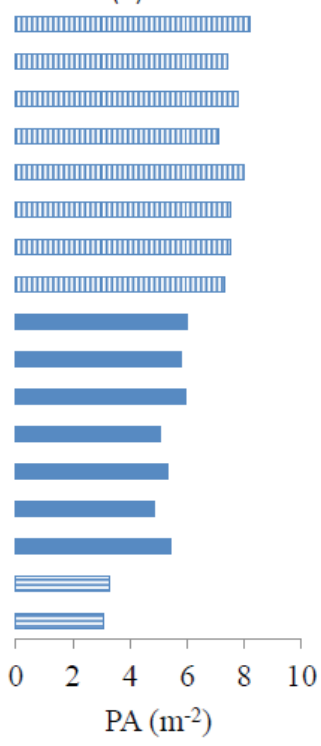

(h)

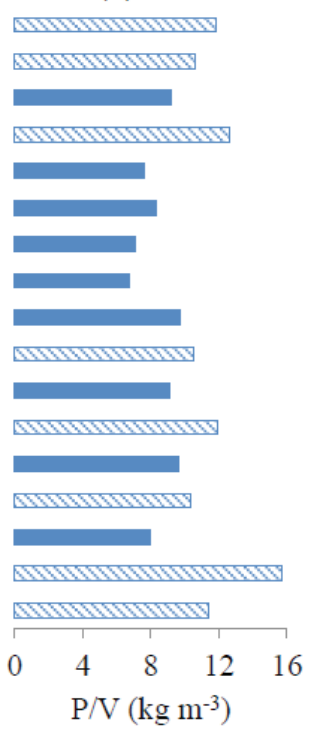

Figure 1. Effect of 17 rootstock genotypes on 'Valência' sweet orange [Citrus sinensis (L.) Osbeck] tree height, canopy shape index, volume $^{1}(\mathrm{~V})$, and projection area (PA), production per tree ${ }^{1}(\mathrm{P})$ and per hectare ${ }^{1}, \mathrm{P} / \mathrm{PA}$ and $\mathrm{P} / \mathrm{N}^{1}$ ratios, cumulated until the fourth harvest season in Águas de Chapecó, Brazil (2013-2019). Bars filled with the same pattern represent no significant differences (Scott-Knott test, $\alpha=0.05)$. 'Variable was transformed

to follow the tree height. This relation is shown in Figure 2, where the arrows corresponding to the three variables above point to approximately the same direction. In the Scott-Knott classification using the average of canopy volume and projection area, the only difference from height classification was 'Cravo', which changed from the mediumheight class to the high-volume and high-area classes (Figures 1c-d).

Valencia on 'San Diego' citrandarin showed the highest cumulated production per tree $(212.13 \mathrm{~kg})$ (Figure 1e). Seven rootstocks comprised a second group, producing $116.39 \mathrm{~kg}$ to $176.61 \mathrm{~kg}$, while other seven produced 74.59 kg to 110.09 kg. 'Flying Dragon' and 'HFD 25 EEl' produced the smallest amount of fruit: 40.83 and 
$54.72 \mathrm{~kg} \mathrm{tree}^{-1}$, respectively. Since all treatments had the same tree density (476.19 trees ha-1), yield per hectare was proportional to tree production, except for 'Cravo', which had three dead trees across two blocks, attributed to Phytophthora $\mathrm{sp}$. rot. Therefore, its production per hectare was proportionally smaller. On the other hand, 'Cravo' showed production per tree and per hectare similar to 'Swingle', 'Sunki' $x$ 'Benecke', 'BRS CNPMF Tropical' and 'Carrizo'. The significant differences between rootstocks regarding tree production were not the same as those for production per hectare (Figure 1e-f). Nevertheless, 'San Diego' maintained its superiority.

Regarding P/PA ratio, rootstocks 'San Diego', 'Swingle', 'Cravo' and 'Sunki' x 'Benecke' stood out with yield ranging from 20.35 to $25.84 \mathrm{~kg} \mathrm{~m}^{-2}$ of canopy projection area (Figure 1g). The highest $\mathrm{P} / \mathrm{N}$ ratio values (Figure $1 \mathrm{~h}$ ) were found in 'HFD 25 EEl', 'Cravo', 'Cravo' x 'Sunki' EEI, 'San Diego', 'Flying Dragon', 'Fepagro C37', 'SCS453 Nasato', 'Swingle' and 'Rubidoux', ranging from 10.35 to $15.71 \mathrm{~kg} \mathrm{~m}^{-3}$ of canopy.

The two principal components in the PCA explained $96 \%$ of the variance in the data. They revealed a strong positive relation between growth variables (height, $\mathrm{V}$, and $\mathrm{PA}$ ) and a strong negative relation between the shape index and P/V ratio, meaning that plants that were more prostrated tended to be more efficient. 'Flying Dragon', for instance, is known by its higher production efficiency per unit of canopy volume induced to the scion (Cantuarias-Avilés, Mourão Filho, Stuchi, Silva and Espinoza-Nuñez, 2011).

'Cravo' is still the main rootstock used in Santa Catarina State, although researchers do not recommend its use due to its sensibility to Phytophthora sp. root rot and frosts and induction of poor scion fruit quality. Trifoliate orange and its hybrids, such as 'Swingle' citrumelo, have been promoted as better genotypes to produce good quality fruits. 'Cravo' and 'Swingle' showed good growth and productive performance in this experiment with 'Valência', although some 'Cravo' trees have died. 'Swingle' has been the main option for growers, since it is well adapted and forms vigorous, good quality fruit producing trees.

The results presented here highlight 'San Diego' citrandarin as a potential rootstock for 'Valência' in southern Brazil and probably in neighboring countries, since it showed the highest yield in the first four harvest seasons (Figures 1e-1f). In PelotasRS, 'San Diego' induced 'Valência' to produce fruit with better color and high polyphenol content, with good yield and vigor (Kirinus et al., 2019). In São
Paulo State, 'San Diego' induced 100 \% survival rate, low alternate bearing, high drought tolerance and yield (Costa, 2019).

Among the rootstocks of intermediate tree size, hybrid 'Cravo' x 'Sunki' EEl (unreleased genotype), combined to 'Valência', formed a highly efficient canopy, producing higher fruit mass per $\mathrm{m}^{3}$ than the rootstocks with similar tree size. However, as 'Cravo' and 'Sunki' genitors have some major weaknesses, the hybrid may have inherited them, especially Phytophthora sensibility (Medina Filho et al, 2003). These traits should be considered in future works before the release of the hybrid as a rootstock cultivar.

Hybrid 'HFD 25 EEl' as rootstock for 'Valencia' performed similarly to 'Flying Dragon', the main dwarfing citrus rootstock. Trees budded on these hybrids were smaller and more prostrated (canopy width larger than height) than the others, with good production per $\mathrm{m}^{3}$. The PCA revealed (Figure 2) that the higher the shape index (more vertical canopies), the lower the P/V ratio. It possibly happens because fruiting limits plant growth (Lliso, Forner and Talón, 2004) and fruit weight causes branches to become decumbent, decreasing the shape index.

The difference between trees of the same scion variety budded on different rootstocks in the same environment are caused, at least in

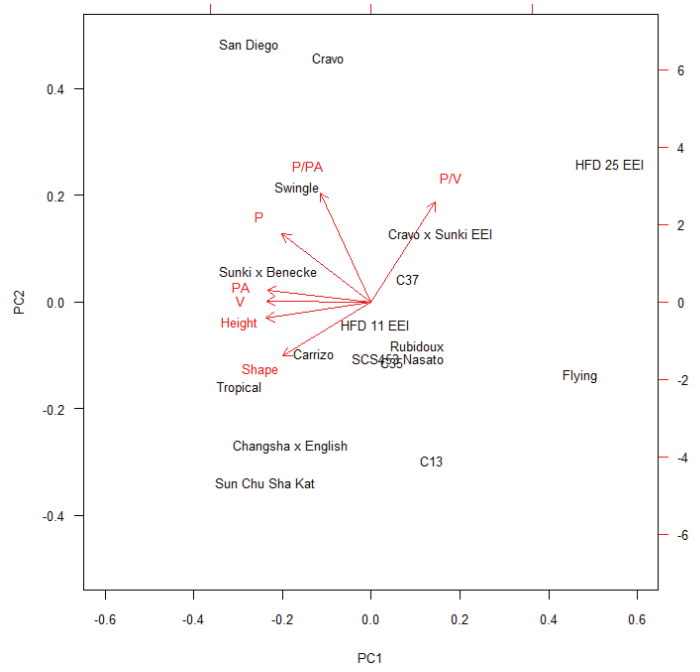

Figure 2. Graphical representation of the two main components PC1 and PC2 (Principal Component Analysis) explaining variance in the observed data for 'Valência' sweet orange [Citrus sinensis (L.) Osbeck] budded on 17 rootstocks. PC1 and PC2 altogether explain $96 \%$ of data variance. The variables analyzed are: tree height, shape index, canopy volume $(\mathrm{V})$ and projection area (PA), tree production $(\mathrm{P}), \mathrm{P} / \mathrm{V}$ and $\mathrm{P} / \mathrm{PA}$ ratios 
part, by the genetic background of the rootstock, which expresses different phenotypical traits. For example, 'Cravo' roots grow deeper than trifoliate orange roots do (Magalhães Filho, Amaral, Machado, Medina and Machado, 2008). Therefore, trees on 'Cravo' can explore a larger soil volume, where it absorbs water and nutrients. Moreover, different root systems vary in growth regulators synthesis, transportation, and distribution resulting in different scion phenotype ( $\mathrm{Liu}, \mathrm{Li}$, Liu, Yao and Chen, 2017). In addition, RNA-transcripts from rootstock genes can migrate to scion and viceversa, and the rootstock can modify the expression of some scion genes (Liu et al., 2018). Some rootstocks have the capacity to change assimilates distribution pattern across the organs as a dwarfing mechanism, that is, fruit load reduces tree growth, following competition for assimilates (Lliso et al., 2004).

Some combinations of rootstocks and scions are not physiologically and biochemically compatible, resulting in bad tissue union and tree decline (Pompeu and Blumer, 2014). This phenomenon could explain bad performance of combinations; however, incompatible combinations with 'Valência' scion seem to be unusual, as Costa (2019) found no evidence of incompatibility among 46 rootstocks with 'Valência'.

Considering that rootstocks provide different growth to scions, comparing ratios $\mathrm{P} / \mathrm{N}$ or $\mathrm{P} / \mathrm{PA}$ provides a better understanding of the rootstock value, since smaller trees can be grown in higher tree density. Therefore, it is better to compare rootstocks within each growth group (canopy volume or area) (Figures 1c-d). Higher efficiency stands out for 'San Diego', 'Swingle', 'Cravo', (big-tree group), 'Cravo' x 'Sunki' EEl, 'Fepagro C37 Dorneles', 'Rubidoux' (medium-tree group), 'HFD25 EEl', and 'Flying Dragon' (small-tree group). However, Koller et al. (1988) reported an increase in production efficiency by $\mathrm{m}^{2}$ of 'Valência'/P. trifoliata from the fifth harvest onward and the opposite for 'Valência'/'Cravo', which means that the results in the present study may not be true for an adult orchard.

Other researchers have studied the same rootstocks in other environments. In Florida (USA), 'Valência' on 'Swingle', and trifoliate orange had similar heights; however, lower than on 'Carrizo' citrange (Castle, Baldwin and Muraro, 2010). In northwestern Paraná State, trees on 'Cravo' produced less than on 'Sunki', without differences neither in canopy height nor in yield efficiency (Auler, Fiori-Tutida and Tazima, 2008). In northern São Paulo State, 'San Diego' did not differ from 'Cravo' clones and 'Sunki Tropical' neither in canopy volume nor in tree production or production efficiency induced to 'Valência'. These findings are not in agreement with this work.

Corroborating the results in the present study, two C. sunki varieties ('Sunki Tropical' and 'Sunki Maravilha') had higher canopy volume compared to other rootstocks (França, Amorim, Girardi, Passos and Soares, 2016). In São Paulo State, 'Valencia' oranges on 'Changsha' mandarin $x$ 'English Large' trifoliate orange and 'Sunki' mandarin $x$ 'Benecke' trifoliate orange crossings did not differ in production per tree, while the later showed more prostrated canopies (Pompeu, Laranjeira and Blumer, 2002), partially agreeing with our data.

Different performances of a same scion/rootstock combination across sites could be attributed to differences in environmental conditions, such as soil biotic and abiotic factors, weather, orchard management, and their interactions. In addition, slight genetic differences may occur between accessions of the same variety (same name) (Snoussi et al., 2012).

\section{CONCLUSION}

Among the rootstocks tested, 'San Diego' citrandarin induces young 'Valência' canopies to produce more fruits per tree and per hectare. Moreover, other rootstocks stand out regarding the number of fruits produced by projection area and canopy volume, namely 'San Diego' citrandarin, 'Swingle' citrumelo, 'Cravo' ('Rangpur') lime, 'Cravo' x 'Sunki' EEl hybrid, 'Fepagro C37 Dorneles' citrange, 'Rubidoux' trifoliate orange, 'HFD25 EEl' hybrid, and 'Flying Dragon' trifoliate orange. These hybrids should be considered mainly in high plant density orchards. 'San Diego', 'Cravo' x 'Sunki' EEI, and 'HFD25 EEl' should be further evaluated regarding disease susceptibility and fruit quality for possible release as commercial rootstocks for 'Valência' sweet orange in Santa Catarina.

\section{ACKNOWLEDGEMENTS}

We thank Mr. Sadi Comel and his family for their kind disposition to offer their farm for growing this experimental orchard. We thank our retired colleague Dr. Osvino L. Koller and Dr. Luana A. C. Maro for helping plan and carry out the project. We also thank the Financiadora de Estudos e Projetos (FINEP) and Fundação de Amparo à Pesquisa e Inovação do Estado de Santa Catarina (FAPESC) for granting financial resources. 


\section{REFERENCES:}

Auler, P. A. M., Fiori-Tutida, A. C. G. and Tazima, Z. H. (2008). Comportamento da laranjeira 'Valência' sobre seis porta-enxertos no noroeste do Paraná. Revista Brasileira de Fruticultura, 30, 229-234. DOI: https://doi. org/10.1590/S0100-29452008000100042

Cantuarias-Avilés, T., Mourão Filho, F. A. A., Stuchi, E. S., Silva, S. R. and Espinoza-Nuñez, E. (2011). Horticultural performance of 'Folha Murcha' sweet orange onto twelve rootstocks. Scientia Horticulturae, 129 (2), 259-265. DOI: https://doi.org/10.1016/j. scienta.2011.03.039

Castle, W. S. (2010). A career perspective on citrus rootstocks, their development, and commercialization. HortScience, 45, 11-15. DOI: https://doi.org/10.21273/ HORTSCI.45.1.11

Castle, W. S., Baldwin, J. C., Muraro, R. P. and Littell, R. (2010). Performance of 'Valencia' sweet orange trees on 12 rootstocks at two locations and an economic interpretation as a basis for rootstock selection. HortScience, 45 (4), 523-533. DOI: https://doi. org/10.21273/HORTSCI.45.4.523

Costa, D. P. (2019). Desempenho horticultural e tolerância à seca de laranjeira 'Valência' sobre portaenxertos híbridos de citros na região norte do Estado de São Paulo. Unpublished Doctoral Dissertation, Universidade Estadual de Santa Cruz, Ilhéus, Bahía, Brazil.

França, N. O., Amorim, M. S., Girardi, E. A., Passos, O. S. and Soares Filho, W. S. S. (2016). Performance of 'Tuxpan Valencia' sweet orange grafted onto 14 rootstocks in northern Bahia, Brazil. Revista Brasileira de Fruticultura, 38 (4), e-684. DOI: https://doi.org/ 10.1590/0100-29452016684

Kirinus, M. B. M., Oliveira, R. P., Silva, P. S., Barreto, C. F., Malgarim, M. B. and Soares Filho, W. S. (2019). Agronomic performance of 'Valência' orange combined with 13 rootstocks in the state of Rio Grande do Sul, Brazil. Pesquisa Agropecuária Brasileira, 54(e00461), 1-9. DOI: https://doi.org/10.1590/010029452016684

Koller, O. C., Marodin, G. A. B., Schwarz, S. F. and Nienow, A. A. (1988). Influência de seis espaçamentos de plantio sobre a produção da laranjeira 'Valência' Citrus sinensis (L.) Osbeck com três porta-enxertos, durante sete safras. Revista Brasileira de Fruticultura, 10 (2), 15-30.

Koller, O. C., Schwarz, S. F. and Panzenhagen, N. V. (1999). Espaçamento de plantio para a laranjeira 'Valência' enxertada em três porta-enxertos. Revista da Agronomia, 12, 1-325.

Liu, T-J., Zhou, J-J., Chen, F-Y., Gan, Z-M., Li, Y-P., Zhang, J-Z. and Hu, C-G. (2018). Identification of the genetic variation and gene exchange between Citrus trifoliata and Citrus Clementina. Biomolecules, 8 (4), 182. DOI: https://doi.org/10.3390/biom8040182

Liu, X-Y., Li, J., Liu, M-M., Yao, Q. and Chen, J-Z. (2017). Transcriptome profiling to understand the effect of citrus rootstocks on the growth of 'Shatangju' mandarin. PLOS ONE, 12, e0169897. DOI: https://doi. org/10.1371/journal.pone.0169897

Lliso, I., Forner, J. B. and Talón, M. (2004). The dwarfing mechanism of citrus rootstocks F\&A 418 and \#23 is related to competition between vegetative and reproductive growth. Tree Physiology, 24 (2), 225-232. DOI: https://doi.org/10.1093/treephys/24.2.225

Magalhães Filho, J. R., Amaral, L. R., Machado, D. F. S. P, Medina, C. L. and Machado, E. C. (2008). Deficiência hídrica, trocas gasosas e crescimento de raízes em laranjeira 'Valência' sobre dois tipos de porta-enxerto. Bragantia, 67, 75-82. DOI: https://doi.org/10.1590/ S0006-87052008000100009

Medina Filho, H. P., Bordignon, R., Siqueira, W. J., Feichtenberger, E., Carvalho, M. R. T. and Teófilo Sobrinho, J. (2003). Resistência de clones e híbridos de porta-enxertos de citros à gomose de tronco causada por Phytophthora parasitica. Fitopatologia Brasileira, 28 (5), 534-540. DOI: https://dx.doi. org/10.1590/S0100-41582003000500011

Pompeu J., Jr. and Blumer, S. (2014). Híbridos de trifoliata como porta-enxertos para laranjeira Pêra. Pesquisa Agropecuária Tropical, 44, 9-14. DOI: https://dx.doi. org/10.1590/S1983-40632014000100007

Pompeu J., Jr., Laranjeira, F. F. and Blumer, S. (2002). Laranjeiras 'Valência' enxertadas em híbridos de trifoliata. Scientia Agricola, 59, 93-97. DOl:https:// dx.doi.org/10.1590/S0103-90162002000100014

R Core Team (2018). R: A language and environment for statistical computing. [Software]. Vienna, Austria: R Foundation for Statistical Computing. Retrieved from: http://www.R-project.org/

Ribeiro, R. V., Espinoza-Núñez, E., Pompeu J., Jr., Mourão Filho, F. A. A. and Machado, E. C. (2014). Citrus rootstocks for improving the horticultural performance and physiological responses under constraining environments. In P. Ahmad, M.R. Wani, M.M. Azooz, y L.-S. Tran (Eds.). Improvement of crops in the era of climatic changes (1-37). New York, United States: Springer.

Rockembach, I. H. and Koller, O. L. (2013). Custo de produção e fluxo de caixa. In O.L. Koller, (Org.) Citricultura catarinense, (311-319). Florianópolis: Epagri.

Snoussi, H., Duval, M., Garcia-Lor, A, Belfalah, Z., Froelicher, Y., Risterucci, A-M... and Ollitrault, P. (2012). Assessment of the genetic diversity of the Tunisian citrus rootstock germplasm. BMC Genetics, 13, 16. DOI: https://doi.org/10.1186/1471-2156-13-16 